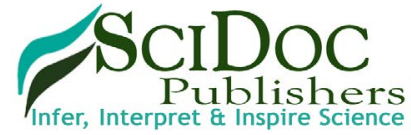

\title{
A Snapshot of Women's Attitudes and Preferences Toward Labor Epidural Analgesia and Cesarean Delivery
}

Research Article

Parajian $\mathrm{T}^{1^{*}}$, Angle $\mathrm{P}^{2,3,4,5,6,7}$, Kurtz Landy $\mathrm{CM}^{8,9}$, Djordjevic J $\mathrm{J}^{10}$

${ }^{1}$ Department of Anesthesia, Faculty of Medicine, University of Toronto, Toronto, ON, Canada.

${ }^{2}$ Director, Obstetrical Anesthesia Research Unit, Sunnybrook Health Sciences Centre, Toronto, ON, Canada.

${ }^{3}$ Associate Scientist, Sunnybrook Research Institute, Sunnybrook Health Sciences Centre, Toronto, ON, Canada.

${ }^{4}$ Associate Professor of Anesthesia, University of Toronto, Toronto, ON, Canada.

${ }^{5}$ Assistant Professor, Clinical Epidemiology, Institute for Health Policy, Management and Evaluation, University of Toronto, Toronto, ON, Canada.

${ }^{6}$ Affiliate Associate Professor, University of British Colombia, Vancouver, BC, Canada.

${ }^{7}$ DPHIL candidate, Evidence Based Health Care Programme, University of Oxford, Oxford, UK.

${ }^{8}$ Assistant Professor, School of Nursing, Faculty of Health, York University, Toronto, ON, Canada.

${ }^{9}$ Assistant Professor (part-time), School of Nursing, Faculty of Health Sciences, McMaster University, Hamilton, ON, Canada.

${ }^{10}$ Research Coordinator, Obstetrical Anesthesia Research Unit, Sunnybrook Health Sciences Centre, Toronto, ON, Canada.

\section{Abstract}

Purpose: Popular media and health services data suggest a shift in pregnant women's attitudes toward increasing acceptance of labor epidural analgesia (LEA) and primary elective cesarean delivery (CD) in North America. We sought to provide a snapshot of women's attitudes towards these interventions within our institution.

Methods: Following REB approval and consent, women were recruited in three groups to participate in a mixed methods survey examining attitudes/preferences for LEA and delivery mode. Groups were: (1) young non-pregnant women (1825 years) from a university campus, (2) pregnant women attending antenatal clinic at Sunnybrook Health Sciences Centre (SHSC), and (3) older (>50 years), non-pregnant women providing non-professional labor support at SHSC.

Results: 281 women participated. Thirty-two percent (38/120) of Group 1, 52\% (54/103) of Group 2, and 64\% (36/56) of Group 3 indicated that they would choose LEA for pain avoidance, to enjoy childbirth, conserve energy, and "no good reason not to". Conversely, 7.5\% (9/120) of Group 1,16\% (16/103) of Group 2 and 16\% (9/56) of Group 3 indicated that they would not want LEA for fear of risks and resistance to medical interventions. Notably, $6 \%(7 / 119)$ of Group 1, 10\% $(10 / 104)$ of Group 2 and 13\% (7/56) of Group 3 indicated a preference for CD to avoid labor pain and perineal injury, maintain control and for perceived safety.

Conclusions: Rising LEA and cesarean rates may reflect their increasing acceptance by women regardless of age and pregnancy status. Further work is required to explore our findings across a larger number of settings.

Keywords: Analgesia; Epidural; Delivery; Obstetrics; Patient Acceptance of Healthcare.

\section{Introduction}

Labor epidural analgesia (LEA) and cesarean delivery (CD) rates are rising across North America. Over half of laboring women in Canada [1] and the United States [2] now receive LEA and approximately one in three women deliver by cesarean section $[3,4]$. Amongst those receiving CD, a small number of women are believed to be opting for primary elective cesarean deliveries, despite the associated risks [5-8].
Studies have historically demonstrated associations between women's acceptance of, or access to, LEA and their education, socioeconomic status, ethnicity, insurance status, and urban versus rural residence, regardless of the type of health care system (public or privately funded) involved [9-12]. More recent work, however, suggests that factors associated with acceptance of LEA or primary elective CD may be changing. For example, research conducted in Canada suggested that healthy multiparous

\footnotetext{
*Corresponding Author:

Talar Parajian MSc MD,

Post Graduate Year-2 Resident, Department of Anesthesia, Faculty of Medicine, University of Toronto, Toronto, Canada.

Tel: (416) 320-7294

E-mail: talarparajian@gmail.com
}

Received: December 04, 2015

Accepted: January 27, 2016

Published: February 01, 2016

Citation: Parajian T, Angle P, Kurtz Landy CM, Djordjevic J (2016) A Snapshot of Women's Attitudes and Preferences Toward Labor Epidural Analgesia and Cesarean Delivery. Int J Anesth Res. 4(2), 200-207. doi: http://dx.doi.org/10.19070/2332-2780-1600047

Copyright: Parajian T $\mathbf{T}^{\circ}$ 2016. This is an open-access article distributed under the terms of the Creative Commons Attribution License, which permits unrestricted use, distribution and reproduction in any medium, provided the original author and source are credited. 
women from rural communities may be choosing to deliver in higher acuity urban centres, at least in part, based on their desire for more ready availability of LEA [13, 14]. Recent research conducted in the UK [15] and Canada [5, 16], suggests that the newer generation of women have become more open to obstetrical interventions during childbirth, including primary elective CD. These observations, coupled with reports of pop icons in the media who have chosen primary elective CD to avoid the "agonizing pain of childbirth" or the risks associated with vaginal birth experienced by their mothers/friends [17], suggest that rising LEA and CD rates may reflect a more general and broad-based shift of women's views, including those of older women, toward acceptance.

The current study is a cross-sectional survey to capture a snapshot of women's attitudes/beliefs toward LEA and elective CD in our setting. We explored women's attitudes across three groups of women representing a spectrum of age, and pregnancy status, including non-pregnant older women.

\section{Methods}

Following Research Ethics approval from Sunnybrook Health Science Centre (SHSC) in March 2012, three groups of women were recruited to participate in this cross-sectional survey. Sampling was by convenience. Group 1 consisted of young adult, non-pregnant women (age 18-25 years) recruited from the University of Toronto campus. Group 2 consisted of nonlaboring pregnant women of any age recruited from the antenatal clinic at SHSC (an academic hospital associated with the University of Toronto). Group 3 consisted of non-pregnant, older women (age $>50$ years) functioning as labor support persons for other women (non-study participants) currently in labor at SHSC. All participants were able to speak, read and write fluently in English. Completion of the survey was deemed evidence of consent by the participant. A sample size was not calculated as this was a mixed methods survey.

\section{Survey Instrument Development and Content}

A validated survey examining preferences and beliefs related to use of epidural analgesia does not exist; therefore a survey tool consisting of 30 questions was developed for the study. Parts of the survey related to cesarean delivery were adapted from a validated reviewed and pilot-tested survey on women's attitudes toward vaginal and cesarean births [16].

The survey instrument for this study contained both forced choice and open-ended questions as part of a mixed methods approach and consisted of three sections. The first section contained multiple-choice questions related to participant demographics and prior history of epidural analgesia. The second section asked participants to state their preference for mode of delivery (vaginal/cesarean/unsure) and use of LEA (yes/no/unsure). They were also asked to describe the reasons for their preferences in an open-ended, short-answer format. The final section of the survey assessed participants' attitudes and beliefs about different aspects of childbirth using a 5-point Likert Scale (Strongly Agree to Strongly Disagree). For example, women were asked to rate statements such as "Giving birth with minimal intervention is important to me". Questions were modified to make them context- appropriate for each group.

Prior to participant recruitment, the face validity of the survey was evaluated by 10 experienced labor and delivery nurses working at SHSC and members of the research team. In addition, 10 medical students at the University of Toronto were asked to review the survey instrument for both content and clarity. Responses and feedback from this process were used to make revisions to the survey instrument prior to its use. The average time to complete the final version of the survey was 10-15 minutes.

\section{Data Collection}

Research personnel not directly involved in patient care invited women to participate in the study and provided the women with a paper survey. Students in public areas at the University of Toronto (E.g. libraries, cafeterias) were also approached and provided with surveys by research personnel. All participants were left to complete the survey alone. Once completed, participants were asked to seal and place the envelope in a collection box. Anonymity was maintained. Survey data were entered into an SPSS database (SPSS Inc., version 18.0. Chicago, SPSS), and verified by research staff.

\section{Analyses}

Quantitative analyses were performed using SPSS. Descriptive statistics including means, standard deviations and percentages were used as appropriate to describe the demographic characteristics of each group. These included age, cultural background, and education level. In order to determine whether there were differences in preference for epidural use and cesarean delivery among the three groups, a chi-square test was used with statistical significance considered $\mathrm{p}<0.05$.

Qualitative thematic content analysis was used to analyze the data from open-ended questions on the survey [18]. Transcripts were independently reviewed by two researchers (TP and PA) with coding derived inductively from the data. Codes reflecting similar ideas within and across the groups were clustered into categories. Investigators (TP, PA) compared codes and emerging themes and established inter-rater consensus. Categories of related themes were then combined to obtain broad overarching themes that gave a holistic view of the data. This process continued until saturation was reached, that is, no concepts requiring new codes were identified.

\section{Results}

398 women were approached of whom 281 participated and were included in the analysis (Group $1 \mathrm{n}=120$, Group $2 \mathrm{n}=104$, Group $3 n=57)$. Demographics reflected the nature of sampling by group (Table 1). Most women (>70\%) in each group were university or college educated or were currently pursuing a post-secondary degree. Forty-four percent of women in Group 2 (currently pregnant) and 95\% of older support women in Group 3 had a history of childbirth, with $40 \%$ and $71 \%$ respectively reporting a history of prior use of LEA.

A greater proportion of women in Groups 2 and 3 reported a preference for LEA (52\% and 64\% respectively) compared with 
Table 1. Demographics.

\begin{tabular}{|c|c|c|c|}
\hline & $\begin{array}{c}\text { Group } 1 \\
\text { Young, Non-pregnant } \\
\mathrm{N}=120\end{array}$ & $\begin{array}{c}\text { Group } 2 \\
\text { Pregnant } \\
\mathrm{N}=104\end{array}$ & $\begin{array}{c}\text { Group } 3 \\
\text { Older support } \\
\mathbf{N}=57\end{array}$ \\
\hline Age, years (Mean \pm SD) & $20.9( \pm 1.7)$ & $33.2( \pm 5.3)$ & $62.0( \pm 5.3)$ \\
\hline History of childbirth (\%) & 0 & 44.2 & 94.7 \\
\hline History of epidural (\%) & 0 & 39.8 & 71.4 \\
\hline Born in Canada (\%) & 39.2 & 64.4 & 52.6 \\
\hline \multicolumn{4}{|l|}{ Ethnicity (\%) } \\
\hline White & 10.8 & 56.7 & 84.2 \\
\hline Black & 3.3 & 7.7 & 5.3 \\
\hline Asian & 40.8 & 16.3 & 3.5 \\
\hline Indian/East Asian & 27.5 & 5.8 & 1.8 \\
\hline Middle Eastern & 6.7 & 4.8 & 1.8 \\
\hline Hispanic/ Latino & 0 & 2.9 & 0 \\
\hline Other & 10.8 & 5.8 & 3.5 \\
\hline \multicolumn{4}{|l|}{ Education (\%) } \\
\hline High school diploma & 5 & 3.8 & 26.3 \\
\hline College diploma & 0 & 22.1 & 33.3 \\
\hline University degree & 95 & 74 & 40.4 \\
\hline
\end{tabular}

$32 \%$ in Group 1 (Table $2 \mathrm{p}=0.01$ ). Similarly, more women in Groups 2 and $3(10 \%$ and $13 \%$ respectively) reported a preference for elective cesarean delivery $(\mathrm{p}=0.02)$.

Major influences on participants' opinions about childbirth are given in Table 3. Unlike Groups 1 and 2 for whom family and friends were reported to be the most important factors influencing their opinions, women in Group 3 cited their own personal experiences to be most important. Interestingly less than a third of women in any group ranked health care providers as a major factor influencing their opinions.

The vast majority $(>80 \%)$ of women in all groups agreed or strongly agreed with the statement, "All women should have the right to an epidural in labor" (Table 4) with most women in Group 2 $(50 \%)$ and Group $3(58 \%)$ agreeing or strongly agreeing with the statement, "Having a pain-free childbirth is important to me". Despite this, the majority of women in Groups 1 and 2 were either neutral or disagreed with the statement, "I would be disappointed if I did not get an epidural' while more than $50 \%$ of women in Group 3, agreed or strongly agreed. Most women in all groups disagreed that "Women who receive an epidural during childbirth miss out on the natural birthing experience" with only a small percentage in each group ( $9 \%$ of Group 1, 19\% of Group 2 and 15\% of Group 3) agreeing or strongly agreeing with the statement, "I would be disappointed if I got an epidural'. With regard to risks associated with epidural analgesia, Group 3 disagreed with concerns that epidural use may harm them or their baby or slow labor progress. Group 1 and 2 were more neutral or undecided about these concerns.

\section{Qualitative analysis}

Major themes emerging from participant responses are provided in Boxes 1 to 3. The first of these, "Why women want epidural pain relief" included four subthemes and described fear of pain, accepting medical intervention, energy conservation for later in labor and to enjoy childbirth (Box 1). Most women described the desire for LEA due to fear and/or avoidance of pain. The final two subthemes, "to ease delivery" and "enjoy childbirth", were specific to Groups 2 and 3.

The second major theme was, "Why women decline epidural analgesia" (Box 2) which had 5 subthemes. These described women's fears of the procedure and associated risks, a desire for a natural childbirth experience and a desire to avoid medical intervention. Group 2 participants specifically reported wanting to challenge themselves to see if they could experience labor and delivery without pain relief.

The third major theme, "Why have an elective cesarean delivery?" (Box 3) had four subthemes including the desire to avoid labor/ pain, avoiding perineal injury, maintaining self-control and perceived safety for the neonate. The last two subthemes were specific to Group 2 and 3 respondents.

\section{Discussion}

This study examined attitudes and preferences toward the use of LEA and elective cesarean delivery across three groups of women who differed by increasing average age, pregnancy status and their status as a support person during labor. We found that most of our sample $(>80 \%)$, of women, regardless of group, felt strongly that women have a right to choose labor epidural pain relief. This finding is consistent with other work in the literature showing that childbearing women expect to have effective pain relief available to them $[13,19,20]$. A significant proportion of women in each group (46\% of Group 1, 50\% of Group 2 and $57 \%$ of Group 3) also agreed or strongly agreed with the statement having a pain-free childbirth is important to me. 
Table 2. Epidural and mode of delivery preference.

\begin{tabular}{|c|c|c|c|c|}
\hline & $\begin{array}{c}\text { Group 1 } \\
\text { Young, Non-pregnant } \\
\mathbf{( \% )}\end{array}$ & $\begin{array}{c}\text { Group 2 } \\
\text { Pregnant } \\
\mathbf{( \% )}\end{array}$ & $\begin{array}{c}\text { Group 3 } \\
\text { Older support } \\
\mathbf{( \% )}\end{array}$ & p-value \\
\hline Epidural & & & & \\
\hline Yes & 31.7 & 52.4 & 64.3 & \\
No & 7.5 & 15.5 & 16.1 & 0.000 \\
I don't know & 60.8 & 32 & 19.6 & \\
\hline Mode of Delivery & & & & \\
\hline Vaginal & 68.1 & 83.7 & 75 & \multirow{2}{*}{0.002} \\
Cesarean Section & 5.9 & 9.6 & 12.5 & \\
I'm not sure & 26.1 & 6.7 & 12.5 & \\
\hline
\end{tabular}

Table 3. Top influences on women's opinions about childbirth.

\begin{tabular}{|c|c|c|c|}
\hline & $\begin{array}{c}\text { Group 1 } \\
\text { Young, } \\
\text { Non-pregnant }\end{array}$ & $\begin{array}{c}\text { Group 2 } \\
\text { Pregnant }\end{array}$ & $\begin{array}{c}\text { Group 3 } \\
\text { Older support }\end{array}$ \\
\hline Friends & 42.5 & 66.7 & 21.4 \\
\hline Family & 87.5 & 56.9 & 39.3 \\
\hline Internet-based information & 20.8 & 34.3 & 7.1 \\
\hline Books & 13.3 & 38.2 & 32.1 \\
\hline Print Media (newspapers, magazines) & 10.0 & 2.0 & 8.9 \\
\hline TV and movies & 41.7 & 10.8 & 3.6 \\
\hline Health care provider & 11.7 & 31.4 & 26.8 \\
\hline School-based information & 37.5 & 2.9 & 7.1 \\
\hline Culture or religion & 15.0 & 3.9 & 5.4 \\
\hline Personal experience & 5.0 & 36.3 & 73.2 \\
\hline
\end{tabular}

Data represents $\%$ of women who chose each influence as their top 3 influences

Table 4. Attitudes and Beliefs about Epidural analgesia.

\begin{tabular}{|c|c|c|c|}
\hline & \begin{tabular}{|c|} 
Group 1 \\
Young, Non-pregnant
\end{tabular} & $\begin{array}{c}\text { Group } 2 \\
\text { Pregnant }\end{array}$ & $\begin{array}{c}\text { Group } 3 \\
\text { Older support }\end{array}$ \\
\hline $\begin{array}{c}\text { All women should have the right } \\
\text { to have an epidural in labor }\end{array}$ & $\begin{array}{c}45.8 \% \text { Strongly agree } \\
36.4 \% \text { Agree }\end{array}$ & $\begin{array}{c}60.0 \% \text { Strongly agree } \\
28.0 \% \text { Agree }\end{array}$ & $\begin{array}{c}52.7 \% \text { Strongly agree } \\
34.5 \% \text { Agree }\end{array}$ \\
\hline $\begin{array}{l}\text { I am scared that the pain in child- } \\
\text { birth will be intense }\end{array}$ & $\begin{array}{c}58.3 \% \text { Strongly agree } \\
33.3 \% \text { Agree }\end{array}$ & $\begin{array}{c}42.2 \% \text { Agree } \\
34.3 \% \text { Strongly agree }\end{array}$ & $\begin{array}{c}42.9 \% \text { Agree } \\
21.4 \% \text { Strongly agree }\end{array}$ \\
\hline $\begin{array}{l}\text { Having a pain-free childbirth is } \\
\text { important to me }\end{array}$ & $\begin{array}{l}34.5 \% \text { Neutral } \\
30.3 \% \text { Agree }\end{array}$ & $\begin{array}{c}35.6 \% \text { Agree } \\
22.8 \% \text { Disagree }\end{array}$ & $\begin{array}{c}45.5 \% \text { Agree } \\
20.0 \% \text { Disagree }\end{array}$ \\
\hline $\begin{array}{c}\text { I would be disappointed if I did } \\
\text { not get an epidural }\end{array}$ & $\begin{array}{l}39.2 \% \text { Neutral } \\
36.7 \% \text { Disagree }\end{array}$ & $\begin{array}{c}27.7 \% \text { Disagree } \\
22.8 \% \text { Neutral } \\
\end{array}$ & $\begin{array}{l}29.1 \% \text { Agree } \\
23.6 \% \text { Neutral }\end{array}$ \\
\hline $\begin{array}{l}\text { I would be disappointed if I got } \\
\text { an epidural }\end{array}$ & $\begin{array}{l}36.7 \% \text { Disagree } \\
31.7 \% \text { Neutral }\end{array}$ & $\begin{array}{c}31.7 \% \text { Disagree } \\
31.7 \% \text { Strongly disagree }\end{array}$ & $\begin{array}{c}38.2 \% \text { Disagree } \\
32.7 \% \text { Strongly disagree }\end{array}$ \\
\hline $\begin{array}{l}\text { Giving birth "naturally ", with } \\
\text { minimal medical intervention, is } \\
\text { important to me }\end{array}$ & $\begin{array}{l}34.7 \% \text { Neutral } \\
24.6 \% \text { Agree }\end{array}$ & $\begin{array}{l}26.0 \% \text { Neutral } \\
24.0 \% \text { Disagree }\end{array}$ & $\begin{array}{c}28.6 \% \text { Disagree } \\
19.6 \% \text { Strongly disagree }\end{array}$ \\
\hline $\begin{array}{l}\text { I believe that epidurals during } \\
\text { childbirth is empowering for } \\
\text { women }\end{array}$ & $\begin{array}{l}55.8 \% \text { Neutral } \\
25.0 \% \text { Disagree }\end{array}$ & $\begin{array}{l}41.0 \% \text { Neutral } \\
27.0 \% \text { Disagree }\end{array}$ & $\begin{array}{l}37.0 \% \text { Neutral } \\
29.6 \% \text { Agree }\end{array}$ \\
\hline $\begin{array}{c}\text { I am afraid of giving birth vagi- } \\
\text { nally }\end{array}$ & $\begin{array}{c}31.9 \% \text { Agree } \\
23.5 \% \text { Strongly agree }\end{array}$ & $\begin{array}{l}30.7 \% \text { Agree } \\
27.7 \% \text { Disagree }\end{array}$ & $\begin{array}{c}42.9 \% \text { Disagree } \\
26.8 \% \text { Strongly disagree }\end{array}$ \\
\hline
\end{tabular}




\begin{tabular}{|c|c|c|c|}
\hline $\begin{array}{c}\text { I am worried about the potential } \\
\text { health risks to myself associated } \\
\text { with an epidural }\end{array}$ & $\begin{array}{c}36.7 \% \text { Agree } \\
22.5 \% \text { Neutral }\end{array}$ & $\begin{array}{c}36.3 \% \text { Agree } \\
24.5 \% \text { Disagree }\end{array}$ & $\begin{array}{c}47.3 \% \text { Disagree } \\
29.1 \% \text { Agree }\end{array}$ \\
\hline $\begin{array}{c}\text { I am worried that an epidural will } \\
\text { affect the way my labor pro- } \\
\text { gresses }\end{array}$ & $\begin{array}{c}39.2 \% \text { Neutral } \\
34.2 \% \text { Agree }\end{array}$ & $\begin{array}{c}35.3 \% \text { Agree } \\
32.4 \% \text { Disagree }\end{array}$ & $\begin{array}{c}39.3 \% \text { Disagree } \\
21.4 \% \text { Neutral }\end{array}$ \\
\hline $\begin{array}{c}\text { I am worried that an epidural may } \\
\text { be harmful to my baby }\end{array}$ & $\begin{array}{c}38.3 \% \text { Agree } \\
23.3 \% \text { Neutral }\end{array}$ & $\begin{array}{c}46.1 \% \text { Disagree } \\
24.5 \% \text { Neutral }\end{array}$ & $\begin{array}{c}50.9 \% \text { Disagree } \\
18.2 \% \text { Neutral }\end{array}$ \\
\hline $\begin{array}{c}\text { I believe that epidural- free child- } \\
\text { birth is empowering for women }\end{array}$ & $\begin{array}{c}40.0 \% \text { Neutral } \\
21.7 \% \text { Disagree }\end{array}$ & $\begin{array}{c}32.7 \% \text { Disagree } \\
19.8 \% \text { Neutral }\end{array}$ & $\begin{array}{c}32.7 \% \text { Disagree } \\
27.3 \% \text { Strongly disagree }\end{array}$ \\
\hline $\begin{array}{c}\text { Women who receive an epidural } \\
\text { during childbirth miss out on the } \\
\text { "natural" birthing experience }\end{array}$ & $\begin{array}{c}34.2 \% \text { Disagree } \\
25.8 \% \text { Neutral }\end{array}$ & $\begin{array}{c}30.7 \% \text { Disagree } \\
26.7 \% \text { Strongly disagree }\end{array}$ & $\begin{array}{c}45.5 \% \text { Disagree } \\
25.5 \% \text { Agree }\end{array}$ \\
\hline $\begin{array}{c}\text { I would be disappointed if I got } \\
\text { an epidural }\end{array}$ & $\begin{array}{c}36.7 \% \text { Disagree } \\
31.7 \% \text { Neutral }\end{array}$ & $\begin{array}{c}31.7 \% \text { Disagree } \\
31.7 \% \text { Strongly disagree }\end{array}$ & $32.7 \%$ Strongly disagree \\
\hline
\end{tabular}

* The 2 most common Likert responses for each group are represented.

\section{Box 1. Factors that contribute to women's desire to have an epidural analgesia.}

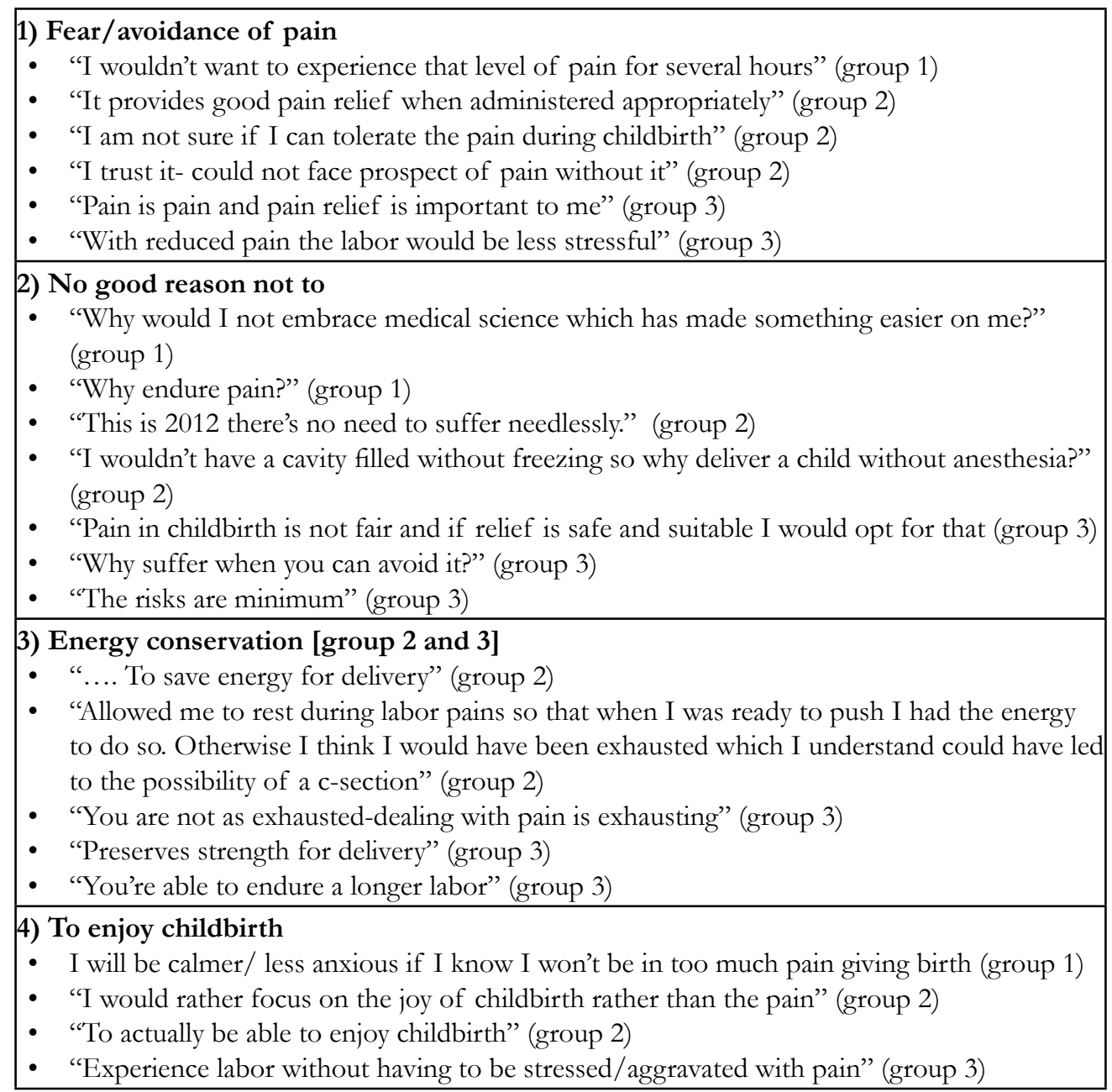

Importantly, the majority of women in our study, regardless of group, disagreed with the statements, I would be disappointed if I received an epidural or that they would miss out on the natural birthing experience. This differs markedly from studies in midwifery patients, where the "working with pain" ethic is promoted. The latter philosophy continues to dominate the wider literature, suggesting that many women hope to give birth without LEA and that they are often dissatisfied with their birth experience when they do receive it [21-25]. Our study is a an explorative study suggesting there may be an emerging shift within our setting in women's attitudes towards use of LEA for labour pain.

Research has shown that younger Canadian obstetricians are more supportive of the role of birth technology than their predecessors, including routine use of LEA. These providers also viewed caesarean delivery as a solution to many perceived labor and birth problems when compared to their predecessors [26]. We hypothesized that younger Canadian women, similar to 
Box 2. Factors that contribute to women's desire to decline epidural analgesia.

1) Fear/avoidance of side effects and risks

- "Scared of bad experience" (group 1).

- "I'm worried it might affect the baby in a negative way" (group 1).

- "May have potential side effects of headaches" (group 1).

- "I'm afraid that epidural can affect the labor in some ways" (group 2).

- "Would like to avoid that groggy feeling" (group 2).

- "I hear it makes baby dopey" (group 2).

- "I want to be able to walk right after" (group 2).

- "I was told to push and had no sensation which was frustrating" (group 3).

2) Desire a natural experience

- "I want the natural experience. I'm considering getting a midwife to deliver my child, I want to connect with my child" (group1).

- "No would not mind a little pain if I get to feel the natural experience of birth" (group 1).

- "I would like to feel every aspect of the birth" (group 2).

- "I would rather do it naturally" (group 2).

- "I think childbirth should be a natural experience" (group 3).

3) Against medicine/ medical intervention

- "I don't believe in medicine" (group 1).

- "Don't approve of antibiotics/drugs" (group 1).

- "I hate medications" (group 2).

- "If delivering vaginally would like to attempt delivery without any interventions" (group 2).

- "I would prefer to try non invasive first such as hypnobirthing" (group 3).

4) Fear of epidural insertion

- "It's scary to get an injection to your spine" (group 1).

- "I'm scared about how painful it will be to take an epidural" (group 1).

- "I have an intense fear of needles" (group 2).

5) Challenge... Can I do it? [group 2 specific]

- "I'm not opposed to epidural but would like to see if I am capable of giving birth without pain relief” (group 2).

- "I want to try to give birth naturally this time although I LOVED my epidural the first time. I want to see if I can do it without one this time. Let's see..." (group 2).

Box 3. Factors that contribute to a woman's desire to have an elective cesarean section.

1) To avoid labor/pain

- "no pushing!!” (group 1)

- "C-section may be less painful!! (group 1)

- "Vaginal delivery seems dreadfully painful" (group 2)

- "No worries of long difficult labors" (group 3)

2) To avoid perineal injury

- "to ensure that I do not have a "loose" vagina after childbirth" (group 1)

- “...to avoid vaginal tears" (group 1)

- “...less pain with c-section and less damage to vaginal area" (group 2)

- "Protecting the pelvic floor is important to avoid incontinence later" (group 2)

- "I would ask for a cesarean because of less damage to uterus and anal muscles" (group 3)

- "fast, neat, quick recovery without ripping and tearing of vagina, other muscles and pulling of bladder out of position" (group 3)

3) To maintain control [group 2 and 3]

- "schedule- can possibly control the delivery date" (group 2)

- "more control over process" (group 2)

- "a cesarean is efficient-can be scheduled" (group 3)

- "C-section can be planned" (group 3)

4) Perceived safety for baby [group 2 and 3]

- "During birth of first child doctor waited too long trying to force vaginal delivery \& baby died by the time c-section done. To alleviate worry + stress I would choose c-section a million times because no mistakes will occur" (group 2)

- "My narrow pelvis could result in injury to the baby" (group 3)

- "C-section is safer for baby" (group 3) 
younger obstetricians would have more open views towards use of LEA and caesarean delivery than older non-pregnant support women in our study.

Contrary to our hypothesis, women across study groups were quite open to the possibility of choosing elective cesarean delivery. Six percent of Group 1, 10\% of Group 2 and 13\% of Group 3 in our study reported a preference for elective caesarean delivery. While women in Groups 2 and 3 might be considered reflective of the more open culture in our hospital, this would not explain findings in Group 1 since the latter women were recruited from a large university campus in downtown Toronto. Our findings in Group 1 are also consistent with two recent studies involving non-pregnant women attending Canadian universities which found that up to $9 \%$ of these women would prefer an elective cesarean delivery with no indication [16] and that 29\% were open to the idea [5]. Of note, women in our study from Group 1 who noted a preference for elective cesarean delivery did not reflect a specific ethnic group making it unlikely that this finding may be accounted for by cultural preferences and practices tied to women of one or a couple ethnicities.

The majority (60\%) of young, non-pregnant women in Group 1 were unsure of whether they intended to receive LEA for childbirth with only $30 \%$ indicating a defined preference in favor of its use. There are a number of possible reasons for greater uncertainty in Group 1. All women were currently non-pregnant and had no history of childbirth therefore they lacked prior experience and/ or reason to have considered their options prior to participation in our survey. The uncertainty in Group 1 may also be indicative of mixed-messages that young women receive about the risks and benefits of LEA since $42 \%$ of women in Group 1 indicated that their beliefs about pain-relief and childbirth were shaped by TV and popular media. Most of the currently pregnant women and older women in the study (52\% of Group 2 and $64 \%$ of Group 3), however, were certain about their intention to receive LEA for childbirth. Based on our findings, pregnant women, and older women commonly seek-out the advice of friends and family, and/or rely on their personal experiences including prior use of LEA to help guide their decision-making. This is consistent with findings from other studies in this area [27-30].

We found that the primary reason women were hesitant to receive LEA was related to their concern about risks and side effects, which is consistent with a recent study by Toledo et al. [31]. The authors of that study noted that many of the fears and concerns voiced by their patients are not supported by the medical literature. Similarly, while some of the concerns raised by the women in our study were valid (e.g. side effect of headaches), others such as "chronic back pain" do not accurately reflect the reality of risks associated with epidural placement [32]. Although women from all three groups voiced concerns, these were more prominent in Groups 1 and 2 who had less personal experience to rely on. Overall, these observations emphasize the importance of having knowledgeable health care providers involved in programs aimed at antenatal counselling to help women make informed decisions.

Desiring a natural experience and resistance to medical intervention were two interrelated themes that were also cited as reasons to forgo LEA in our study. Group 2 participants specifically described wanting to "challenge" themselves and "see if they can do it". These are viewpoints that seem to be highlighted in popular media in articles which glorify, applaud and/or romanticize individual cases of women who gave birth "naturally" without pain relief $[33,34]$, or exaggerate the risks associated with epidurals $[35,36]$. While this was the viewpoint of a minority of our population, it was reported in all three groups and was most prevalent in Groups 1 and 2 which included the most women with no prior personal experience with childbirth (100\% Group 1, 56\% Group 2).

Surprisingly, less than a third of currently pregnant women in our population indicated that their health care provider was a major influence in their decision making surrounding use of LEA. Information available on the internet was more influential in decision making than their health care provider. While it is not possible to state whether popular media has had a direct effect on women's decision-making or simply reflects changes occurring in women's attitudes and preferences in the population, our findings do suggest that women's attitudes and preferences are more open to the range of pain management and delivery choices, regardless of group, than we expected.

One of the weaknesses of this study is that sampling of Groups 2 and 3 were from a single institution where epidural analgesia is readily available and has a high utilization rate (ie. $80-85 \%$ ). This however does not explain findings in Group 1 where almost a third had a defined preference in favor of LEA and $6 \%$ preference rate for elective primary cesarean delivery in this same group. Notably, our analysis of this group showed that the latter preference was not attributable to a single ethnic group.

The degree to which our findings for Groups 2 and 3 are generalizable outside of our institution is not certain. Differences in women's use of LEA between institutions may be related to their availability and may reflect important cultural differences as well. It would be interesting to replicate this study in these different settings to examine differences that may exist.

Our study had several strengths. These included use of a mixed methods approach to data collection using both closed and open survey questions, permitting more rigorous assessment of the factors that influenced women's decision-making related to use of LEA and their preferred delivery mode. The sample size recruited for each group was also large compared to many such studies in the literature $[5,20,30]$.

The results of our study have important implications for antenatal counselling. Maternity care providers must address women's concerns and fears related to method of delivery and the use of LEA based on current best evidence. Anesthesiologists should take an active role in developing appropriate education materials and participate in patient childbirth education sessions.

Finally, women in our study clearly voiced that they believed they had a right to effective labour analgesia and did not view access to LEA as elective. Recent research has shown that significant barriers exist to provision of obstetrical anesthesia services in small and rural community hospitals in Canada [13]. Women delivering in urban non-teaching hospitals, and particularly in small and rural communities may have similar attitudes and preferences regarding CD and LEA, and yet may not have access to the same level of care as the participants in our study. Future work is required to explore women's attitudes and preferences toward use of LEA and $\mathrm{CD}$ in these settings. 


\section{Acknowledgement}

This research was funded by The Langar Foundation.

\section{References}

[1]. Canadian Institute of Health Information. Childbirth Indicators by Place of Residence Report. 2013-2014; Available from URL:http://apps.cihi.ca/ mstrapp/asp/Main.aspx?Server=apmstrextprd_i\&rproject=Quick+Stats\&uid =pce_pub_en\&pwd=\&evt=2048001\&visualizationMode=0\&documentID $=029$ DB170438205AEBCC75B8673CCE822.

[2]. Osterman MJK, Martin JA (2011) Epidural and Spinal Anesthesia Use During Labor: 27-state Reporting Area, 2008. http://www.cdc.gov/nchs/data/ nvsr/nvsr59/nvsr59_05.pdf

[3]. Canadian Institute for Health Information. Health Indicators 2013. https:// secure.cihi.ca/free_products/HI2013_EN.pdf

[4]. Martin JA, Hamilton BE, Osterman MJK, Curtin SC, Mathews TJ (2015) Births: Final data for 2013. Natl vital Stat Rep 64(1): 1-65. http://www.cdc. gov/nchs/data/nvsr/nvsr64/nvsr64_01.pdf

[5]. Gallagher F, Bell L, Waddell G, Benoît A, Côté N (2012) Requesting cesareans without medical indications: An option being considered by young Canadian women. Birth 39(1): 39-47.

[6]. D'Souza R, Arul kumaran S (2013) To 'C' or not to 'C'? Caesarean delivery upon maternal request: a review of facts, figures and guidelines. J Perinat Med 41(1): 5-15.

[7]. Reilly DR (2009) Caesarean section on maternal request: how clear medical evidence fails to produce ethical consensus. J Obstet Gynaecol Can 31(12): 1176-1179.

[8]. D'Souza R (2013) Caesarean section on maternal request for non-medical reasons: putting the UK National Institute of Health and Clinical Excellence guidelines in perspective. Best Pract Res Clin Obstet Gynaecol 27(2): 165-177.

[9]. Rust G, Nembhard WN, Nichols M, Omole F, Minor P, et al. (2004) Racial and ethnic disparities in the provision of epidural analgesia to Georgia Medicaid beneficiaries during labor and delivery. Am J Obstet Gynecol 191(2): 456-462.

[10]. Glance LG, Wissler R, Glantz C, Osler TM, Mukamel DB, et al. (2007) Racial Differences in the Use of Epidural Analgesia for Labor. Anesthesiology 106(1): 19-25.

[11]. Liu N, Wen SW, Manual DG, Katherine W, Bottomley J, et al. (2010) Social disparity and the use of intrapartum epidural analgesia in a publicly funded health care system. Am J Obstet Gynecol 202(3): 273.e1-8.

[12]. Koteles J, de Vrijer B, Penava D, Xie B (2012) Maternal characteristics and satisfaction associated with intrapartum epidural analgesia use in Canadian women. Int J Obstet Anesth 21(4): 317-323.

[13]. Angle P, Kurtz Landy C, Murthy Y, Cino P (2009) Key issues and barriers to obstetrical anesthesia care in Ontario community hospitals with fewer than 2,000 deliveries annually. Can J Anesth 56(9): 667-677.

[14]. Angle P, Kurtz Landy C, Charles C, Yee J, Watson J, et al. (2010) Phase 1 development of an index to measure the quality of neuraxial labour analgesia: exploring the perspectives of childbearing women. Can J Anesth 57(5): 468-478.

[15]. Green JM, Bastom HA (2007) Have Women Become More Willing to Accept Obstetric Interventions and Does This Relate to Mode of Birth? Data from a Prospective Study. Birth 34(1): 6-13.

[16]. Stoll K, Fairbrother N, Carty E, Jordan N, Miceli C, et al. (2009) It's all the rage these days: University students' attitudes toward vaginal and cesarean birth. Birth 36(2): 133-140.

[17]. Gruber R. 23 Celebrities who've given birth via c-section. [Internet]. [Place unknown]: Pop Sugar; 2015 Feb 16 [cited 2015 May 25]. Available from: http://www.popsugar.com/moms/Celebrities-Who-Have-Given-Birth-ViaC-Section-18174762\#photo-18174762

[18]. Hsieh HF, Shannon SE (2005) Three approaches to qualitative content analysis. Qual Health Res 15(9): 1277-1288.

[19]. Lally JE, Murtagh MJ, Macphail S, Thomson R (2008) More in hope than expectation: a systematic review of women's expectations and experience in pain relief in labour. BMC Med 6:7.

[20]. Orbach-Zinger S, Bardin R, Berestizhevsky Y, Sulkes J, David Y, et al. (2008) A survey of attitudes of expectant first time fathers and mothers towards epidural analgesia for labor. Int J Obstet Anesth 17(3): 243-246.

[21]. Morgan BM, Bulpitt CJ, Clifton P, Lewis PJ (1982) Analgesia and satisfaction in childbirth (the Queen Charlotte's 1000 mother survey). Lancet 2(8302): 808-810

[22]. Hodnett ED (2002) Pain and women's satisfaction with the experience of childbirth: A systematic review. Am J Obstet Gynecol 186(5 Suppl): S160S172.

[23]. Kannan S, Jamison RN, Datta S (2001) Maternal Satisfaction and Pain Control in Women Electing Natural Childbirth. Reg Anesth Pain Med 26(5): 468-472.

[24]. Hodnett ED, Gates S, Hofmeyr GJ, Sakala C, Weston J (2011) Continuous support for women during childbirth. Cochrane Database Syst Rev (2): CD003766.

[25]. Hatem M, Sandall J, Devane D, Soltani H, Gates S (2008) Midwife-led versus other models of care for childbearing women. Cochrane Database Syst Rev (4): CD004667.

[26]. Klein MC, Liston R, Fraser WD, Baradaran N, Hearps SJ, et al. (2011) Attitudes of the new generation of Canadian obstetricians: how do they differ from their predecessors? Birth 38(2): 129-139.

[27]. Emmett CL, Shaw AR, Montgomery AA, Murphy DJ, DiAMOND study group (2006) Women's experience of decision making about mode of delivery after a previous caesarean section: The role of health professionals and information about health risks. BJOG 113(12): 1438-1445.

[28]. Moffat MA, Bell JS, Porter MA, Lawton S, Hundley V, et al. (2007) Decision making about mode of delivery among pregnant women who have previously had a caesarean section: A qualitative study. BJOG 114(1): 86-93.

[29]. McCourt C, Weaver J, Statham H, Beake S, Gamble J, Creedy DK (2007) Elective cesarean section and decision making: A critical review of the literature. Birth 34(1): 65-79.

[30]. Van den Bussche E, Crombez G, Eccleston C, Sullivan MJ (2007) Why women prefer epidural analgesia during childbirth: The role of beliefs about epidural analgesia and catastrophizing. Eur J Pain 11(3): 275-282.

[31]. Toledo P, Sun J, Peralta F, Grobman WA, Wong CA, et al. (2013) A qualitative analysis of parturients' perspectives on neuraxial labor analgesia. Int J Obstet Anesth 22(2): 119-123.

[32]. Anim-Somuah M, Smyth RM, Jones L (2011) Epidural versus non-epidural or no analgesia in labour. Cochrane DB Syst Rev (12): CD000331.

[33]. Pain in childbirth 'a good thing'. BBC News [Internet]. 2009. http://news. bbc.co.uk/2/hi/8147179.stm

[34]. Everyday HEALTH [Internet]. [Place unknown]: Everyday Health Clinic. http://www.whattoexpect.com/celebrity/photo-gallery/celebrities-naturalbirths.aspx\#

[35]. Kresser C (2011) Natural childbirth V: epidural side effects and risks. [Internet]. [Place unknown]. http://chriskresser.com/natural-childbirth-v-epidural-side-effects-and-risks/

[36]. Mayo-Laakso M (2010) The Hidden Risk of Epidurals. [Internet]. [Place unknown]: Mothering.http://www.mothering.com/articles/the-hidden-riskof-epidurals/ 